\title{
Study of the soil respiration and evaporation of ten soybean varieties in the field conditions from SCDA Turda
}

\author{
Zamfira DINCĂ, Roxana VIDICAN* Ioan Rotar and Mignon ȘANDOR \\ Faculty of Agriculture, University of Agricultural Sciences and Veterinary Medicine, \\ Calea Manastur Street, No. 3-5, 400372, Cluj-Napoca, Romania; \\ * corresponding author: roxana.vidican@usamvcluj.ro \\ Bulletin USAMV series Agriculture 71(2)/2014 \\ Print ISSN 1843-5246; Electronic ISSN 1843-5386 \\ DOI 10.15835/buasvmcn-agr: 10763
}

\begin{abstract}
Soil respiration is an important indicator of soil biological activity. Respiration rate can be influenced by soil temparature, moisture conditions, plant root densities and activities, soil organism population levels, soil physical and chemical properties, etc. The results obtained by measuring soil respiration evaporation on 10 soybean varieties in flowering phenophase shows significant differences for 8 of the 10 species considered in the study.
\end{abstract}

Keywords: Glycine $\max ($ L.) Merr., soil respiration, soil evaporation.

Introduction. Soil respiration is an important component of the carbon dynamics of terrestrial ecosystems. Knowledge of soil respiration dynamics is essential to find proper management policies and relevant technologies to decrease soil $\mathrm{CO}_{2}$ emissions and enhance carbon sequestration (Peng et al., 2010).

Aims and objectives. The present study aims to determine the soil respiration and evaporation of 10 soybean genotypes in the same experimental conditions, fertilization and treatments applied.

Materials and methods. The experience was located of the clay-alluvial ferozium vertic soil from SCDA Turda. The experimental design was organized by randomized block method with 10 variants, in three repetitions and the biological material was represented by 10 varieties of soybean created at SCDA Turda. Measuring of the soil respiration and evaporation was performed using closed dynamic system CIRAS 2 (PP System, USA) in July of 2013.

Results and Discussion. The soil respiration values of soybean genotypes register insignificant differences, only one genotype (Onix) recorded values of $2.44 \mathrm{~g} / \mathrm{m} 2 / \mathrm{h}$, which is found to be significantly negative compared to controls (Table 1 ).

Data analysis of soil evaporation reveals a variation of this indicator between 0,05 and 0,65 $\mathrm{g} / \mathrm{m}^{2} / \mathrm{h}$. One variety (Eugen) recorded values of $0,65 \mathrm{~g} / \mathrm{m}^{2} / \mathrm{h}$, which is found significantly positive to the control. (Table 2).

Conclusion: The results obtained in 2013, in the SCDA Turda conditions, revealed that soil respiration and evaporation show values that are found insignificant in 8 of the 10 genotypes studied, only varieties Onix and Eugen recorded significant values of the indicators studied.

\section{REFERENCES}

1. Parkin T. B., Kaspar T. C., Senwo Z., Pruger J. H. and Hatfield J. L. (2005). Relationship of soil respiration to crop and landscape in the Walnut Creek Watershed. Journal of Hidrometeorology. Volume 6: 812-824.

2. Raich J., W. and Tufekcioglu A. (1999). Vegatation and soil soil respiration: correlations and controls. Biogeochemistry 48: 71-90.

3. Peng Q., Dong Y., Qi Y., Xiao S., He Y., Ma T., 2010. Effect of nitrogen fertilization on soil respiration in temperate grassland in Inner Mongolia, China. Environ. Earth Sci. DOI 10.1007/s12665-010-0605-4.

4. Șandor M. (2010). Respirația solului: Concept și metode de determinare. ProEnvironment, Nr.5, Vol. 3, Cluj-Napoca.

5. Vidican Roxana (2007). Microbiologie. Editura Risoprint, Cluj Napoca, 55-60. 
Tab.1. Results on soil respiration

\begin{tabular}{cccccc}
\hline Variety & $\begin{array}{c}\text { Soil } \\
\text { evaporation }\end{array}$ & $\begin{array}{c}\text { \% to the } \\
\text { martor }\end{array}$ & $\begin{array}{c}\text { Difference from } \\
\text { control }\end{array}$ & $\begin{array}{c}\text { Significance } \\
\text { of difference }\end{array}$ & Duncan Test \\
\hline Diamant -control & 0,20 & 100 & 0 & Mt. & A \\
\hline Perla & 0,25 & 125,4 & 0,05 & - & $\mathrm{A}$ \\
\hline Agat & 0,38 & 193,1 & 0,18 & - & $\mathrm{A}$ \\
\hline Safir & 0,10 & 49,2 & $-0,10$ & - & $\mathrm{AB}$ \\
\hline Opal & 0,65 & 330,5 & 0,45 & $*$ & $\mathrm{AB}$ \\
\hline Onix & 0,41 & 206,8 & 0,21 & - & $\mathrm{AB}$ \\
\hline Felix & 0,25 & 127,1 & 0,05 & - & $\mathrm{AB}$ \\
\hline Darina & 0,08 & 39,0 & $-0,12$ & - & $\mathrm{AB}$ \\
\hline Cristina TD & 0,18 & 91,5 & $-0,02$ & - & $\mathrm{AB}$ \\
\hline Mălina TD & 0,05 & 25,4 & $-0,15$ & - & \\
\hline DL (p 5\%) & & & & & \\
0,44 & & & & \\
DS & & & & \\
DL (p 1\%) & & & & \\
0,61 & & & & \\
0,44-0,51 & & & & \\
DL (p 0,1\%) & & & & \\
0,83 & & & & & \\
\hline
\end{tabular}

Tab. 2

\begin{tabular}{cccccc}
\hline Variety & $\begin{array}{c}\text { Soil } \\
\text { evaporation }\end{array}$ & $\begin{array}{c}\text { \% to the } \\
\text { martor }\end{array}$ & $\begin{array}{c}\text { Difference } \\
\text { from control }\end{array}$ & $\begin{array}{c}\text { Significance of } \\
\text { difference }\end{array}$ & Duncan Test \\
\hline Diamant - control & 0,20 & 100 & 0 & Mt. & A \\
\hline Perla & 0,25 & 125,4 & 0,05 & - & $\mathrm{A}$ \\
\hline Agat & 0,38 & 193,1 & 0,18 & - & $\mathrm{A}$ \\
\hline Safir & 0,10 & 49,2 & $-0,10$ & - & $\mathrm{AB}$ \\
\hline Opal & 0,65 & 330,5 & 0,45 & $*$ & $\mathrm{AB}$ \\
\hline Onix & 0,41 & 206,8 & 0,21 & - & $\mathrm{AB}$ \\
\hline Felix & 0,25 & 127,1 & 0,05 & - & $\mathrm{AB}$ \\
\hline Darina & 0,08 & 39,0 & $-0,12$ & - & $\mathrm{AB}$ \\
\hline Cristina TD & 0,18 & 91,5 & $-0,02$ & - & $\mathrm{AB}$ \\
\hline Mălina TD & 0,05 & 25,4 & $-0,15$ & - & $\mathrm{B}$ \\
\hline DL (p 5\%) & & & 0,44 & & $0,44-0,51$ \\
DL (p 1\%) & DL (p 0,1\%) & & & 0,83 & \\
\hline
\end{tabular}

Results on soil evaporation 